\title{
Correspondence
}

\section{Social workers and children in care}

SIR

With regard to the paper 'Children in Care: Are Social Workers Abusing Their Authority?' which appeared in the September 1983 JME. In December 1983 I was invited to contribute a brief paper to a seminar organised by the London Medical Group. Other papers were given by a barrister and a director of social services. My paper described as briefly as possible my perception of three disputed child care cases and my contribution as a child psychiatrist to furthering the understanding of those cases. In each case important aspects of the emotional development between child and parent had been overlooked not only by social workers, but also by other experts such as teachers and child health specialists. All the cases I described lived within a few miles of competent child psychiatric services and yet in none had a psychiatric opinion been sought.

I hoped the papers of all three of us would be published. Since they were not may I briefly summarise the other two. The barrister spoke in terms of despair at how he perceived social workers who seemed in his opinion to be determined to obtain care orders through the courts with little respect for the rights of children or parents. The director of social services spoke of his local authority's choice of what he cabled 'an aggressive fostering policy'. (He did not quote the monetarist booklet that set out the alleged advantages of such policies (1).)

Judy Foster in her response to my paper reminds us of the legal and political framework within which social workers must carry out their duties. She points out that social workers have to deal with the elderly, the mentally il and the physically handicapped and that work with children and families is a small proportion of their work. She says that most social workers are 'generalists' as opposed to specialists. Somehow she argues that this exonerates them from obtaining information from specialists such as myself on the grounds that child psychiatrists are too few and far between (a criticism I agree with). She goes on to say we are too busy to leave our clinics to see families in their own homes and unable to make contact with parents with little or no English at their command. Neither of these arguments apply to the hospital departments of child psychiatry and child guidance clinics that I am familiar with.

There are likely to be some people within all professions who do not trust each other or who do not trust people from other professions. However, interprofessional trust is the mainstay of good work in the multidisciplinary teams that have operated in child guidance clinics in ever increasing numbers since the first was set up in 1928. I am proud to have been part of several such teams during the last 25 years. Judy Foster is wrong to assume that because people disagree they necessarily mistrust one another. A more helpful response might be to enter into discussion to see why differing views had emerged about the same case.

It seems to me that disputed care cases arise because there is lack of agreement about when a child should be received into care, what should happen to him once in care and whether or not access to his own family is desirable.

May I recommend some further reading concerning these issues? $(2,3$, 4).

\section{References}

(1) The provision of child care : a study at eight local authorities in England and Wales - final report. Bristol : District Audit, 1981.

(2) Tunnard J, ed. Fostering parental contact. London: Family Rights Group, 1982.

(3) Benians $\mathrm{R}$ et al. Children and family breakdown, custody and access : guidelines, the need for a new approach. London: Families Need Fathers, 1983.

(4) Oxtoby M, ed. Taking a stand: child psychiatrists in custody, access and disputed adoption cases. London: British Agencies for Adoption \& Fostering, 1984.

R C BENIANS

Consultant Psychiatrist

3 Brodrick Road, London, SW17 7DZ. 